Type of the Paper (Article, Review, Communication, etc.)

\title{
One-pot Syntheses Using Carbonyl Compounds Catalyzed by Ce(III) Supported on a Weakly Acidic Cation-exchanger Resin
}

\author{
Eva Havránková ${ }^{1}$, Pavel Pazdera ${ }^{1, *}$ \\ ${ }^{1, *}$ Centre for Syntheses at Sustainable Conditions and Management, Chemistry Department, Masaryk \\ University, Kamenice 5, CZ-625 00 Brno, Czech Republic; E-Mail: pazdera@chemi.muni.cz
}

External Editor:

Received: / Accepted: / Published:

\begin{abstract}
One of the possibilities to sophisticate compound syntheses is catalysis using supported catalyst which combines the advantages of both homogeneous and heterogeneous catalyst. An application of $\mathrm{Ce}(\mathrm{III})$ inorganic salts, first of all $\mathrm{CeCl}_{3} .7 \mathrm{H}_{2} \mathrm{O}$ doped by sodium iodide, not until has been described from start of 21 st Century. Twenty communications has been present during this time only. Catalysis by Ce(III) salts has been used for an activation of carbonyl compounds and their derivatives in syntheses. Easily available, cheap mechanically and thermally stable industrial cation-exchangers may be used as carriers ${ }^{1}$. These in connection with complex of cerium in oxidation state of $3^{+}$ provide an effective, easily separable and recyclable catalytic system. This system has been studied with a view to its possible synthetic applications on model three-component domino syntheses, i.e. Kabachnik-Fields one-pot synthesis of $\alpha$-aminophosphonates ${ }^{2}$, and Prins-Ritter one-pot synthesis of 4-amidotetrahydropyran derivatives ${ }^{3}$, respectively. It has been discovered that cation Ce(III) supported on a weak acid macroporous cationexchanger has shown in the studied reactions at least the same or better catalytic activity as salt $\mathrm{CeCl}_{3} .7 \mathrm{H}_{2} \mathrm{O}$, eventually doped by $\mathrm{NaI}$.
\end{abstract}

Keywords: $\alpha$-aminophosphonates; 4 -amidotetrahydropyranes; metal catalysis; polymer supported Ce(III); solid support catalysis. 


\section{Introduction}

Molecule containing phosphonate are highly biologically potent. They can be used as inhibitors of synthase $^{4}$, HIV protease ${ }^{5}$, PTPases ${ }^{6,7}$, rennin $^{8}$, enzymes ${ }^{9}$, antibiotics ${ }^{10}$, herbicides ${ }^{11}$, and ect.

Generally $\alpha$-aminophosphonates can be prepared by addition of phosphorous nucleophiles to imines in the presence of acids ${ }^{12-14}$ or in three-component synthesis of amines, aldehydes and triethylphosphites with Lewis and Brønsted acids as catalysts. In this case as catalysts can be used $\mathrm{FeCl}_{3}{ }^{15}, \mathrm{ZrCl}_{4}{ }^{16}, \mathrm{SbCl}_{3} / \mathrm{Al}_{2} \mathrm{O}_{3}{ }^{17}$, amberlyst- $15^{18}$, sulfamic acid ${ }^{19}, \mathrm{BF}_{3} \cdot \mathrm{Et}_{2} \mathrm{O}^{20}$, and so.

4-Amido tetrahydropyran derivatives are often present in natural products as a glycamino acid ${ }^{21,22}$, ambruticins $\mathrm{VS}^{23,24}$ and others. 4-Amido tetrahydropyran derivatives can be generally prepared by the Prins-Ritter synthesis ${ }^{25-27}$.

At the turn of the century lanthanide Lewis acids, as cerium(III) chloride $\left(\mathrm{CeCl}_{3} .7 \mathrm{H}_{2} \mathrm{O}\right)$, have attracted an attention in organic synthesis due to their high reactivity, stability, ease of handling, air tolerance, low toxicity and low $\operatorname{cost}^{28,29}$. Cerium(III) is the most commonly used as chloride or nitrate salt itself or supported on silica gel eventually doped by sodium iodide - this type of supported catalyst was developed by Bartoli and Marcantoni ${ }^{30,31}$.

Solid supported catalysts combine the advantages of both heterogeneous and homogenous catalysts $^{32,33}$. They have high selectivity, reactivity, and stability. They are easily separable and recyclable. Due to these characteristics they are suitable for reactions carried out in accordance with the principles of Green Chemistry ${ }^{34}$.

The one-pot syntheses, by minimizing the number of intermediate synthetic steps and therefore minimizing the amount of waste, are very suitable type of syntheses for Green Chemistry ${ }^{34}$.

\section{Results and Discussion}

To prove the efficiency of the catalytic system of $\mathrm{Ce}$ (III) cations supported on weakly acidic macroporous cation exchanger, we performed a comparative study on two model domino syntheses.

The first of them was the preparation of $\alpha$-aminophosphonates published previously in ${ }^{2}$. Catalytic system used in this case featured the $10 \mathrm{~mol} \%$ of cerium trichloride heptahydrate $\mathrm{CeCl}_{3} \cdot 7 \mathrm{H}_{2} \mathrm{O}$. The second model synthesis was one-pot synthesis of 4-amidotetrahydropyran derivatives published previously in ${ }^{3}$, where $5 \mathrm{~mol} \%$ of $\mathrm{CeCl}_{3} .7 \mathrm{H}_{2} \mathrm{O}$ was used as a catalyst.

We verified the both model synthetic procedures with published catalysts according to the general procedure published in ${ }^{2}$ and ${ }^{3}$ respectively. Syntheses were then carried out with Ce(III) supported on above described resin and the results were compared in terms of the reaction time and the yield relative to the used catalytic system. 
Figure 1. General scheme of the preparation of $\alpha$-aminophosphonates derivatives and possible cerium(III) including key intermediates of syntheses.<smiles>[R]c1ccc(C(=O)[CH+][Al]N)cc1</smiles>

key intermediates:
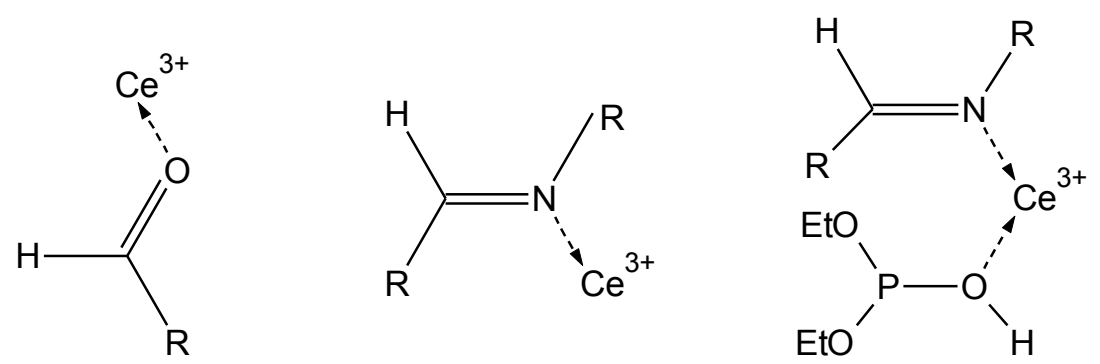

Results of $\alpha$-aminophosphonates study revealed that the Ce(III) cation supported on the resin provided at least as satisfying results as other catalytic systems, the results in Table 1 show the greatest shortening of reaction times and the maximal yields for the catalytic system $\mathrm{Ce}$ (III) supported on the weakly acidic cation exchanger.

The role of $\mathrm{Ce}$ (III) cations as a catalyst in this procedure can be explained by the key intermediates (Fig.1). Coordination of $\mathrm{Ce}$ (III) ion to the oxygen of the carbonyl functional group in applied aldehyde increases the electron withdrawing character of this group and thus facilitates the formation of bond between nitrogen of amine and the carbon atom in carbonyl group.

In the case of syntheses of 4-amidotetrahydropyran derivatives, the reactions catalyzed by $\mathrm{Ce}$ (III) ions were in general much faster and yields were higher than in the case of uncatalyzed reactions, similarly as in the previous model syntheses. The highest yields and the shortest reaction times were again observed when procedures were catalyzed by catalytic system Ce(III) supported on the weakly acidic cation exchanger. Details are demonstrated in Table 2. 
Table 1. Preparation of $\alpha$-aminophosphonates derivatives - table of results.

\begin{tabular}{|c|c|c|c|c|c|c|}
\hline Entry & & Reactants & Catalytic system & $\begin{array}{c}\text { Molar Ratio } \\
\text { [eqv] }\end{array}$ & $\begin{array}{l}\text { Yield } \\
{[\%]}\end{array}$ & Time $[\mathrm{min}]$ \\
\hline \multirow{6}{*}{1} & $\mathrm{a}$ & \multirow{6}{*}{$\begin{array}{l}\text { Benzaldehyde; } \\
\text { Aniline; } \\
\text { Diethyl phosphite }\end{array}$} & - & $1: 1,1$ & N.R. & 1440 \\
\hline & $\mathrm{b}$ & & $\mathrm{CeCl}_{3} \cdot 7 \mathrm{H}_{2} \mathrm{O}^{2}$ & $1: 1,1: 0,03$ & 95 & 300 \\
\hline & $\mathrm{c}$ & & $\mathrm{CeCl}_{3} .7 \mathrm{H}_{2} \mathrm{O} / \mathrm{NaI}$ & $1: 1,1: 0,03$ & 96 & 240 \\
\hline & $\mathrm{d}$ & & $\mathrm{CeCl}_{3} .7 \mathrm{H}_{2} \mathrm{O} / \mathrm{NaI}$ supported on resin & $1: 1,1: 0,03$ & 98 & 220 \\
\hline & $\mathrm{e}$ & & $\mathrm{CeCl}_{3} .7 \mathrm{H}_{2} \mathrm{O} / \mathrm{NaI}$ supported on silica gel & $1: 1,1: 0,03$ & 93 & 330 \\
\hline & $\mathrm{f}$ & & Proline $/ \mathrm{CeCl}_{3} .7 \mathrm{H}_{2} \mathrm{O} / \mathrm{NaI}$ supported on resin & $1: 1,1: 0,03$ & 96 & 180 \\
\hline \multirow{6}{*}{2} & a & \multirow{6}{*}{$\begin{array}{c}\text { 4- } \mathrm{CH}_{3} \mathrm{O} \text {-Benzaldehyde; } \\
\text { Aniline; } \\
\text { Diethyl phosphite }\end{array}$} & - & $1: 1,1$ & N.R. & 1440 \\
\hline & $\mathrm{b}$ & & $\mathrm{CeCl}_{3} .7 \mathrm{H}_{2} \mathrm{O}^{2}$ & $1: 1,1: 0,03$ & 91 & 270 \\
\hline & $\mathrm{c}$ & & $\mathrm{CeCl}_{3} .7 \mathrm{H}_{2} \mathrm{O} / \mathrm{NaI}$ & $1: 1,1: 0,03$ & 93 & 240 \\
\hline & $\mathrm{d}$ & & $\mathrm{CeCl}_{3} \cdot 7 \mathrm{H}_{2} \mathrm{O} / \mathrm{NaI}$ supported on resin & $1: 1,1: 0,03$ & 93 & 180 \\
\hline & e & & $\mathrm{CeCl}_{3} .7 \mathrm{H}_{2} \mathrm{O} / \mathrm{NaI}$ supported on silica gel & $1: 1,1: 0,03$ & 90 & 280 \\
\hline & $\mathrm{f}$ & & Proline $/ \mathrm{CeCl}_{3} .7 \mathrm{H}_{2} \mathrm{O} / \mathrm{NaI}$ supported on resin & $1: 1,1: 0,03$ & 94 & 150 \\
\hline \multirow{6}{*}{3} & $\mathrm{a}$ & \multirow{6}{*}{$\begin{array}{l}\text { 4- } \mathrm{NO}_{2} \text {-Benzaldehyde; } \\
\text { Aniline; } \\
\text { Diethyl phosphite }\end{array}$} & - & $1: 1,1$ & N.R. & 1440 \\
\hline & $\mathrm{b}$ & & $\mathrm{CeCl}_{3} .7 \mathrm{H}_{2} \mathrm{O}^{2}$ & $1: 1,1: 0,03$ & 90 & 780 \\
\hline & $\mathrm{c}$ & & $\mathrm{CeCl}_{3} .7 \mathrm{H}_{2} \mathrm{O} / \mathrm{NaI}$ & $1: 1,1: 0,03$ & 92 & 660 \\
\hline & $\mathrm{d}$ & & $\mathrm{CeCl}_{3} .7 \mathrm{H}_{2} \mathrm{O} / \mathrm{NaI}$ supported on resin & $1: 1,1: 0,03$ & 94 & 600 \\
\hline & e & & $\mathrm{CeCl}_{3} .7 \mathrm{H}_{2} \mathrm{O} / \mathrm{NaI}$ supported on silica gel & $1: 1,1: 0,03$ & 90 & 780 \\
\hline & $\mathrm{f}$ & & Proline $/ \mathrm{CeCl}_{3} .7 \mathrm{H}_{2} \mathrm{O} / \mathrm{NaI}$ supported on resin & $1: 1,1: 0,03$ & 94 & 420 \\
\hline \multirow{6}{*}{4} & a & \multirow{6}{*}{$\begin{array}{r}\text { Benzaldehyde; } \\
\text { 4-Cl-Aniline; } \\
\text { Diethyl phosphite }\end{array}$} & - & $1: 1,1$ & N.R. & 1440 \\
\hline & $\mathrm{b}$ & & $\mathrm{CeCl}_{3} .7 \mathrm{H}_{2} \mathrm{O}^{2}$ & $1: 1,1: 0,03$ & 93 & 540 \\
\hline & $\mathrm{c}$ & & $\mathrm{CeCl}_{3} .7 \mathrm{H}_{2} \mathrm{O} / \mathrm{NaI}$ & $1: 1,1: 0,03$ & 94 & 420 \\
\hline & $d$ & & $\mathrm{CeCl}_{3} \cdot 7 \mathrm{H}_{2} \mathrm{O} / \mathrm{NaI}$ supported on resin & $1: 1,1: 0,03$ & 97 & 360 \\
\hline & $\mathrm{e}$ & & $\mathrm{CeCl}_{3} .7 \mathrm{H}_{2} \mathrm{O} / \mathrm{NaI}$ supported on silica gel & $1: 1,1: 0,03$ & 91 & 560 \\
\hline & $\mathrm{f}$ & & Proline $/ \mathrm{CeCl}_{3} .7 \mathrm{H}_{2} \mathrm{O} / \mathrm{NaI}$ supported on resin & $1: 1,1: 0,03$ & 96 & 270 \\
\hline \multirow{6}{*}{5} & $\mathrm{a}$ & \multirow{6}{*}{$\begin{array}{l}\text { Benzaldehyde; } \\
\text { 4-Aminophenol; } \\
\text { Diethyl phosphite }\end{array}$} & - & $1: 1,1$ & N.R. & 1440 \\
\hline & $\mathrm{b}$ & & $\mathrm{CeCl}_{3} .7 \mathrm{H}_{2} \mathrm{O}^{2}$ & $1: 1,1: 0,03$ & 90 & 600 \\
\hline & $\mathrm{c}$ & & $\mathrm{CeCl}_{3} .7 \mathrm{H}_{2} \mathrm{O} / \mathrm{NaI}$ & $1: 1,1: 0,03$ & 94 & 420 \\
\hline & $\mathrm{d}$ & & $\mathrm{CeCl}_{3} .7 \mathrm{H}_{2} \mathrm{O} / \mathrm{NaI}$ supported on resin & $1: 1,1: 0,03$ & 96 & 350 \\
\hline & e & & $\mathrm{CeCl}_{3} .7 \mathrm{H}_{2} \mathrm{O} / \mathrm{NaI}$ supported on silica gel & $1: 1,1: 0,03$ & 93 & 510 \\
\hline & $\mathrm{f}$ & & Proline $/ \mathrm{CeCl}_{3} .7 \mathrm{H}_{2} \mathrm{O} / \mathrm{NaI}$ supported on resin & $1: 1,1: 0,03$ & 96 & 280 \\
\hline
\end{tabular}

*At room temperature; ethanol as a solvent.

Acceleration of the reaction in the presence of $\mathrm{Ce}$ (III) cations can be explained by the the key intermediates (Fig.2). Coordination of $\mathrm{Ce}$ (III) cation to the carbonyl oxygen of aldehyde raises electron deficiency on this group and thus facilitates the bond formation between the oxygen of but-3en-1-ol and the carbon of an aldehyde group. 
Figure 2. General scheme of the preparation of 4-amidotetrahydropyran derivatives and possible cerium(III) including key intermediates of syntheses.<smiles>[R]c1ccc(C=O)cc1</smiles>

key intermediates:<smiles>[R]C=[Co]</smiles><smiles>[R]C1C=CCC([R])O1</smiles>

Table 2. Preparation of 4-amidotetrahydropyran derivatives - table of results.

\begin{tabular}{|c|c|c|c|c|c|c|}
\hline Entry & & Reactants & Catalytic system & Molar Ratio [eqv] & $\begin{array}{c}\text { Yield } \\
{[\%]}\end{array}$ & $\begin{array}{l}\text { Time } \\
\text { [min] }\end{array}$ \\
\hline \multirow{4}{*}{1} & $\mathrm{a}$ & \multirow{4}{*}{$\begin{array}{l}\text { Acetyl chloride; } \\
\text { But-3-en-1-ol; } \\
\text { Benzaldehyde }\end{array}$} & - & $1,5: 1,2: 1$ & 31 & 1440 \\
\hline & $\mathrm{c}$ & & $\mathrm{CeCl}_{3} \cdot 7 \mathrm{H}_{2} \mathrm{O} / \mathrm{NaI}^{3}$ & $1,5: 1,2: 1: 0,05$ & 84 & 420 \\
\hline & d & & $\mathrm{CeCl}_{3} .7 \mathrm{H}_{2} \mathrm{O} / \mathrm{NaI}$ supported on resin & $1,5: 1,2: 1: 0,05$ & 86 & 360 \\
\hline & $\mathrm{e}$ & & $\mathrm{CeCl}_{3} .7 \mathrm{H}_{2} \mathrm{O} / \mathrm{NaI}$ supported on silica gel & $1,5: 1,2: 1: 0,05$ & 82 & 450 \\
\hline \multirow{4}{*}{2} & $\mathrm{a}$ & \multirow{4}{*}{$\begin{array}{c}\text { Acetyl chloride; } \\
\text { But-3-en-1-ol; } \\
\text { 4- } \mathrm{CH}_{3} \mathrm{O}-\text { Benzaldehyde }\end{array}$} & - & $1,5: 1,2: 1$ & 45 & 1440 \\
\hline & $\mathrm{c}$ & & $\mathrm{CeCl}_{3} .7 \mathrm{H}_{2} \mathrm{O} / \mathrm{NaI}^{3}$ & $1,5: 1,2: 1: 0,05$ & 93 & 360 \\
\hline & d & & $\mathrm{CeCl}_{3} .7 \mathrm{H}_{2} \mathrm{O} / \mathrm{NaI}$ supported on resin & $1,5: 1,2: 1: 0,05$ & 93 & 220 \\
\hline & $\mathrm{e}$ & & $\mathrm{CeCl}_{3} .7 \mathrm{H}_{2} \mathrm{O} / \mathrm{NaI}$ supported on silica gel & $1,5: 1,2: 1: 0,05$ & 89 & 360 \\
\hline \multirow{4}{*}{3} & $\mathrm{a}$ & \multirow{4}{*}{$\begin{array}{c}\text { Acetyl chloride; } \\
\text { But-3-en-1-ol; } \\
\text { 4- } \mathrm{NO}_{2} \text {-Benzaldehyde }\end{array}$} & - & $1,5: 1,2: 1$ & 38 & 1440 \\
\hline & $\mathrm{c}$ & & $\mathrm{CeCl}_{3} .7 \mathrm{H}_{2} \mathrm{O} / \mathrm{NaI}^{3}$ & $1,5: 1,2: 1: 0,05$ & 82 & 450 \\
\hline & $\mathrm{d}$ & & $\mathrm{CeCl}_{3} .7 \mathrm{H}_{2} \mathrm{O} / \mathrm{NaI}$ supported on resin & $1,5: 1,2: 1: 0,05$ & 84 & 340 \\
\hline & $\mathrm{e}$ & & $\mathrm{CeCl}_{3} .7 \mathrm{H}_{2} \mathrm{O} / \mathrm{NaI}$ supported on silica gel & $1,5: 1,2: 1: 0,05$ & 80 & 480 \\
\hline \multirow{4}{*}{4} & $\mathrm{a}$ & \multirow{4}{*}{$\begin{array}{l}\text { Acetyl chloride; } \\
\text { But-3-en-1-ol; } \\
\text { Cyclohexanone }\end{array}$} & - & $1,5: 1,2: 1$ & 35 & 1440 \\
\hline & $\mathrm{c}$ & & $\mathrm{CeCl}_{3} \cdot 7 \mathrm{H}_{2} \mathrm{O} / \mathrm{NaI}^{3}$ & $1,5: 1,2: 1: 0,05$ & 90 & 480 \\
\hline & d & & $\mathrm{CeCl}_{3} .7 \mathrm{H}_{2} \mathrm{O} / \mathrm{NaI}$ supported on resin & $1,5: 1,2: 1: 0,05$ & 91 & 400 \\
\hline & $\mathrm{e}$ & & $\mathrm{CeCl}_{3} .7 \mathrm{H}_{2} \mathrm{O} / \mathrm{NaI}$ supported on silica gel & $1,5: 1,2: 1: 0,05$ & 88 & 500 \\
\hline
\end{tabular}

*At room temperature; acetonitrile as a solvent and nucleophilic reagent.

\section{Experimental Section}

\subsection{Materials}

All reagents were purchased from commercial suppliers and used as received without further purification. Purolite C 104 Plus (Purolite ${ }^{\circledR}$ Worldwide), i.e. weakly acidic polyacrylic cation- 
exchanger resin of macroporous type, $\mathrm{H}^{+}$ionic form, total volume capacity $4.5 \mathrm{eq} / \mathrm{L}$, specific gravity $1.19 \mathrm{~g} / \mathrm{mL}$, was used as solid support.

All the reactions were monitored by TLC performed on precoated Silica gel 60 F254 plates (Merck). Synthesis of $\alpha$-aminophosphonates: ethanol was used as eluent; UV light (254 and $356 \mathrm{~nm}$ ) and ninhydrine reagent were used for detection of spots. Synthesis of 4-amidotetrahydropyran: $\mathrm{Et}_{2} \mathrm{O}$ was used as eluent; UV light (254 and $356 \mathrm{~nm}$ ) was used for detection of spots.

All products were identified by NMR and IR methods, and by measurement of melting point.

${ }^{1} \mathrm{H}-\mathrm{NMR}$ and ${ }^{13} \mathrm{C}$-NMR spectra were recorded on DRX 300 Avance (BrukerBiospin) spectrometer using tetramethylsilane as an internal standard.

Melting points are uncorrected and were recorded on Kofler's block BoetiusRapido PHMK 79/2106 (Wägetechnik), temperature gradient $4{ }^{\circ} \mathrm{C} \mathrm{min}^{-1}$.

\subsection{Catalyst Preparation}

3.2.1. $\mathrm{Ce}(\mathrm{III})$ cations, $\mathrm{NaI}$ and eventual proline supported on cation exchanger

The catalytic system containing Ce(III) cations supported on a weakly acidic macroporous cation exchanger of polyacrylate type was prepared according to the patent ${ }^{1}$. Purolite C 104 Plus (75 g) was suspended in $200 \mathrm{~mL}$ of water and a saturated aqueous potassium carbonate solution was added under stirring until $\mathrm{pH}$ of the solution remained at value of 12 for $10 \mathrm{~min}$ after the last addition. Then the aqueous solution was decanted and the resin beads were washed 4 times by $200 \mathrm{~mL}$ of water. Cerium(III) chloride heptahydrate $(122.7 \mathrm{~g}, 33 \mathrm{mmol})$ was dissolved in $500 \mathrm{~mL}$ of water and modified resin beads were dropped into the solution which was then stirred overnight. Then the aqueous solution was again decanted and the resin beads were washed 2 times by $200 \mathrm{~mL}$ of water. Next the aqueous solution of sodium iodide ( $30.0 \mathrm{~g}, 0.2 \mathrm{~mol}$ ) in $250 \mathrm{~mL}$ of water was added and the mixture was stirred overnight. After decantation of water phase from resin beads and their washing by water was added an eventual aqueous solution of proline $(23.0 \mathrm{~g}, 0.2 \mathrm{~mol})$ in $250 \mathrm{~mL}$ of water, mixture was stirred overnight and then water solution was decanted. Finally, solid phase was washed 2 times by $200 \mathrm{~mL}$ of water, 2 times by $200 \mathrm{~mL}$ of methanol and finally dried in vacuum to constant weight. The prepared catalyst contained about $2.3 \mathrm{mmol}$ of $\mathrm{Ce}$ (III) per $1 \mathrm{~g}$ of modified resin beads ${ }^{1}$. Catalyst is also available from TauChem Ltd., Bratislava, Slovakia, http://www.tau-chem.sk/en/About/Companydescription.alej.

\subsection{2. $\mathrm{Ce}(\mathrm{III})$ cations and NaI supported on silica gel}

The catalytic system containing $\mathrm{Ce}$ (III) cations and $\mathrm{NaI}$ supported on silica gel was prepared according to the article ${ }^{19}$. Silica gel was added to a mixture of $\mathrm{CeCl}_{3} .7 \mathrm{H}_{2} \mathrm{O}$ and $\mathrm{NaI}$ in acetonitrile, and this mixture was stirred overnight at room temperature. The acetonitrile was removed by rotary evaporator 
and the resulting mixture was used as a catalyst. This catalytic system containing $0.65 \mathrm{mmol}$ $\mathrm{CeCl}_{3} .7 \mathrm{H}_{2} \mathrm{O}$ and $0.65 \mathrm{mmol} \mathrm{NaI}$ on $1.00 \mathrm{~g}$ of silikagel.

\subsection{General Synthetic Procedures}

3.3.1. General procedure for preparation of $\alpha$-aminophosphonates ${ }^{2}$ :

A mixture of $2 \mathrm{mmol}$ of amine, $2.2 \mathrm{mmol}$ of diethyl phosphite, and $2 \mathrm{mmol}$ of aldehyde with appropriate catalytic system in $5 \mathrm{~mL}$ of ethanol as a solvent, was stirred at room temperature until disappearance of amine from the reaction mixture. The reaction was monitored by TLC. After the completion of reaction, the reaction mixture was heated until the precipitated crystals dissolved. Than the product was precipitated by adding ice water, filtrated off and washed with cold water. Obtained ${ }^{1} \mathrm{H},{ }^{13} \mathrm{C}$ NMR and FT IR spectral data of all synthesized products were in agreement with published data $^{2}$.

3.3.2. General procedure for preparation of 4-amidotetrahydropyranes ${ }^{3}$ :

A mixture of $1.2 \mathrm{mmol}$ of but-3-en-1-ol, $1 \mathrm{mmol}$ of carbonyl compounds, and $1.5 \mathrm{mmol}$ of acetyl chloride with appropriate catalytic system in $5 \mathrm{~mL}$ of acetonitrile as a solvent and at the same nucleophilic reagent, was stirred at room temperature until disappearance of carbonyl compound from the reaction mixture. The reaction was monitored by TLC. After the completion of reaction, the reaction mixture was quenched with water and extracted with $2 \times 10 \mathrm{~mL}$ of ethyl acetate. The combined organic layers were dried with anhydrous $\mathrm{Na}_{2} \mathrm{SO}_{4}$ and purified with silica gel. Acquired ${ }^{1} \mathrm{H},{ }^{13} \mathrm{C}$ NMR and FT IR spectral data of obtained products were in accordance with published data ${ }^{3}$.

\section{Conclusions}

In conclusion, a comparative studies of application a new catalyst - Ce(III) supported on weekly acidic cation exchanger resin and catalysts based on $\mathrm{Ce}$ (III) chloride were applied to one-pot syntheses of $\alpha$-aminophosphonates, and 4-amidotetrahydropyran derivatives. It was found that the $\mathrm{Ce}$ (III) cation supported on the resin provided at least as effective as other catalytic systems used so far and moreover takes advantage in simple separation and reusing. Solid support was realized with low-cost industrial resin resulting in further savings. The used organic resin has not abrasive effect on surface of reaction vessels, in contradistinction to silica gel carrier. In conclusion the advantages of the present protocol make the procedure an attractive alternative to the existing methods for the synthesis of $\alpha$-aminophosphonates, and 4-amidotetrahydropyran derivatives. The efficiency of all applied catalytic systems depends on the character of the present functional group in the starting carbonyl compound.

\section{References}


1. Pazdera, P.; Zberovská, B.; Němečková, D.; Datinská, V.: CZ 2011/0799 (A3).

2. Jafari, A. A.; Nazarpour, M., Abdollahi-Alibeik, M.; Heteroatom Chemistry, 2010, 21, 397-403.

3. Yadav, J. S.; Subba Reddy, B. V.; Narayana Kumar, G. G. K. S.; Madhusudhan Reddy, G.; Tetrahedron Letters, 2007, 48, 4903-4906.

4. Sikorski, J. A.; Miller, M. J.; Braccolino, et al.; Phosphorus Sulfur Silicon, 1993, 76, 375-378.

5. Stowasser, B.; Budt, K. H.; Jian-Qi, L.; Peyman, A.; Ruppert, D.; Tetrahedron Lett., 1992, 33, 6625-6628.

6. Bruke, T. R.; George, C.; Wolf, G.; Shoelson, S. E.; Yan, X.; J. Med. Chem., 1995, 38, 13861396.

7. Bruke, T. R.; Kole, H. K.; Roller, P. P.; Biochem. Biophys. Res. Commun., 1994, 204, 129134.

8. Patel, D. V.; Rielly-Gauvin, K.; Ryono, D. E.; Tetrahedron Lett., 1990, 31, 5587-5591.

9. Peyman, A.; Budt, K. H.; Paning, J. S.; Stowasser, B.; Ruppert, D.; Tetrahedron Lett., 1992, 33, 4549-4552.

10. Atherton, F. R.; Hassall, C. H.; Lambert, R. W.; J. Med. Chem., 1986, 29, 29-40.

11. Kafarski, P.; Lejczak, B.; Mastalerz, P.; Chem. Abstr., 1985, 103, 174532.

12. Laschat, S.; Kunz, H.; Synthesis, 1992, 90-95.

13. Kudzin, Z. H.; Lyzwa, P.; Luczak, J.; Andrijewski, G.; Synthesis, 1997, 44-47.

14. Lee, S.-G.; Park, J. H.; Kang, J.; Lee, J. K.; Chem. Commun., 2001, 1698-1699.

15. Ranu, B. C.; Hajra, A.; Jana, U.; Org. Lett., 1999, 1, 1141-1143.

16. Rezaei, Z.; Firouzabadi, H.; Iranpoor, N., Ghaderi, A., et al.; Eur. J. Med. Chem., 2009, 44, 4266-4275.

17. Ambica, S.; Kumar, S. C.; Taneja, M. S.; Hundal,K.; Kapoor, K.; Tetrahedron Lett., 2008, 49, 2208-2212.

18. Tajbakhsh, M.; Heydari, A.; Alinezhad, H.; Ghanei, M.; Khaksar, S.; Synthesis, 2008, 352-354.

19. Mitragotri, S. D.; Pore, D. M.; Desai, U. V.; Wadgaonkar, P. P.; Catal. Commun., 2008, 9, 1822-1826.

20. Ha, H.-J.; Nam, G.-S.; Synth. Commun., 1992, 22, 1143-1148.

21. Suhara, Y.; Yamaguchi, Y.; Collins, B.; et al.; Bioorg. Med. Chem., 2002, 10, 1999-2013.

22. Hofle, G.; Steimnetz, H.; Gerth, K.; Reichenbach, H.; Liebigs. Ann. Chem., 1991, 941.

23. Snider, B. B.; Hawryluk, N.; Org. Lett., 2000, 2, 635-638.

24. Michelet, V.; Genet, J.-P.; Curr. Org. Chem., 2005, 9, 405-418.

25. Yadav, J. S.; Reddy, M. S.; Rao, P. P.; Prasad, A. R.; Tetrahedron Lett., 2006, 47, 4397-4401.

26. Yadav, J. S.; Reddy, M. S.; Prasad, A. R.; Tetrahedron Lett., 2006, 47, 4937-4941.

27. Yadav, J. S.; Reddy, M. S.; Prasad, A. R.; Tetrahedron Lett., 2006, 47, 4995-4998.

28. Molander, G. A.; Chemical Reviews, 1992, 92, 29-68.

29. Imamoto, T.; Lanthanides in Organic Synthesis, XVII Ed., San Diego, Academic Press, 1994.

30. Bartoli, G.; Bosco, M.; Marcantoni, E.; Petrini, M.; Sambri, L.; Torregiani, E.; J. Org. Chem., 2001, 66, 9052-9055.

31. Bartoli, G.; Bartolacci, M.; Bosco, M.; et al.; J. Org. Chem., 2003, 68, 4595-4597. 
32. Choplin, A.; Quignard, F.; Bosco, M.; Foglia, G.; Giuliani, A.; Marcantoni, E.; et al.; Coord. Chem. Rev., 1998, 178-180, 1679-1702.

33. Ahluwalia, V.K.; Aggarwal, R.; Organic Synthesis: Special Techniques, 2nd Ed., Alpha Science International, Oxford, 2006.

34. Pazdera, P.; Chapter 1. Emerging Ubiquity of Green Chemistry in Engineering and Technology, in: Handbook on Applications of Ultrasound-Sonochemistry for Sustainability, 1st ed., CRC Press/Taylor \& Francis Group, Boca Raton FL USA, 2011. 